\title{
"Cinderella" elements: strategies to increase the stability of group 1 complexes by tailoring crown macrocycles
}

Aurora Rodríguez-Rodríguez, Israel Carreira-Barral, David Esteban-Gómez, Carlos Platas-Iglesias, $\underline{\text { Andrés de Blas }^{*}, \text { Teresa Rodríguez-Blas }}$

Departamento de Química Fundamental, Facultad de Ciencias, Universidade da Coruña, Campus da Zapateira-Rúa da Fraga 10, 15008 A Coruña, Spain

Inorganica Chimica Acta, volume 417, pages 155-163, 01 June 2014

Available online 26 November 2013

\section{How to cite:}

"Cinderella" Elements: Strategies to Increase the Stability of Group 1 Complexes by Tailoring Crown Macrocycles. Aurora Rodríguez-Rodríguez, Israel Carreira-Barral, David Esteban-Gómez, Carlos Platas-Iglesias, Andrés de Blas, and Teresa Rodríguez-Blas. Inorganica Chimica Acta 2014 417, 155 163. DOI: 10.1016/j.ica.2013.11.022.

(C) 2014. This manuscript version is made available under the CC Attribution-NonCommercial-

NoDerivatives 4.0 International license: http://creativecommons.org/licenses/by-nc-nd/4.0.

\begin{abstract}
The synthesis and structural characterization of six sodium complexes with bibracchial lariatethers containing aniline or benzimidazole side arms, and derived from 1,7-diaza-12-crown-4, 1,10-diaza-15crown-5 or 4,13-diaza-18-crown-6, are reported. The X-ray structures of four of these compounds have been obtained. Additionally, the X-ray structures of a sodium macrobicyclic complex derived from 1,10-diaza-15crown-5, and a potassium complex with a bibracchial lariat ether containing aniline side arms are also reported. Bonding distances as well as the stability constants in acetonitrile solution confirm that the coordination of the pendant arms provides an important contribution to the overall stability of the complexes, particularly when benzimidazole pendants are present rending more stable complexes, even more than cryptand complexes of the same size. Compared with the parent crown ethers, the stability increases when the side arms contain benzimidazole moieties but remains about the same order when aniline side arms are present.
\end{abstract}

Keywords: macrocyclic ligands; x-ray crystal structures; crown ethers; alkaline metal complexes; lariat ether

\section{Introduction}

The publication in 1967 by Charles J. Pedersen of two works ${ }^{[1,2]}$ describing methods of synthesising cyclic polyethers, which he named crown ethers, and their complexes with metal salts, represented a breakthrough for the development of the coordination chemistry with macrocyclic ligands. Pedersen showed

*andres.blas@udc.es 
that these compounds have remarkable coordination properties and that they can even bind the alkali metal ions. He also stated the selectivity of the crown ether depending on the relative size of the metal ion and the macrocyclic cavity of the crown ether.

To improve the properties or the coordination ability of those ligands, the donor atom set may be modified. Today, crown and aza-crown ethers constitute an important class of macrocyclic multidentate receptors extensively used in metal ion separations ${ }^{[3,4]}$. The coordination chemistry of the group 1 metal ions with crown ethers has been explored, ${ }^{[5]}$ and these studies show that often aditional ligands are required to complete the coordination sphere around the metal ion.

Attachment of side arms with potential metal ion binding sites to a (aza)crown ether gives lariat ethers ${ }^{[6]}$, which provide a three dimensional complexation that often results in enhanced cation binding affinity and selectivity in comparison to the parent macrocycle ${ }^{[7,8]}$. Due to their interesting recognition properties, crown and lariat ethers have found many applications in different areas that include: (i) preparation of ion-selective electrodes ${ }^{[9,10]}$ and stationary phases in chromatographic techniques ${ }^{[11]}$; (ii) separation and transport processes for the recovery or removal of metal ions ${ }^{[12]}$; (iii) their use as phase-transfer catalysts in organic reactions ${ }^{[13,14]}$; and (iv) the design of chromogenic or fluorogenic chemosensors ${ }^{[15-17]}$. Furthermore, crown ethers have also considerable biochemical relevance as models of natural ionophores ${ }^{[18]}$. More recently it has also been suggested that crown ethers may find application as novel anticancer drugs ${ }^{[19]}$.

In previous papers we have reported the coordinative properties of cryptands and bibracchial lariat ethers incorporating aniline or benzimidazole pendant arms towards transition metal ions, lanthanide, and alkalineearth metal ions ${ }^{[20-24]}$. As a continuation of these works, herein we report a structural study both in the solid state and solution of alkaline complexes with the bibracchial lariat ethers $\mathbf{L}^{1}-\mathbf{L}^{\mathbf{6}}$ and cryptands $\mathbf{L}^{7}$ and $\mathbf{L}^{\mathbf{8}}$ (Scheme 1). The aim of the present study is to investigate the effect of the additional coordination positions incorporated in the side arms joined to the crown moiety on the coordinative properties and the stability of this family of closely related complexes.

\section{Experimental}

\subsection{Reagents}

$N, N^{\prime}$-bis(benzimidazole-2ylmethyl)-1,7-diaza-12-crown-4 $\quad\left(\mathbf{L}^{\mathbf{1}}\right)^{[25]}, N, N^{\prime}$-bis(2-aminobenzyl)-1,7-diaza-12crown-4 $\quad\left(\mathbf{L}^{2}\right)^{[26]}, N, N^{\prime}$-bis(benzimidazole-2ylmethyl)-1,10-diaza-15-crown-5 $\quad\left(\mathbf{L}^{3}\right)^{[25]}, N, N^{\prime}$-bis(2aminobenzyl)-1,10-diaza-15-crown-5 $\quad\left(\mathbf{L}^{4}\right)^{[27]}, N, N^{\prime}$-bis(benzimidazole-2ylmethyl)-4,13-diaza-18-crown-6 $\left(\mathbf{L}^{5}\right)^{[28]}, N, N^{\prime}$-bis(2-aminobenzyl)-4,13-diaza-18-crown-6 $\left(\mathbf{L}^{\mathbf{6}}\right)$ and macrobicyclic receptors $\mathbf{L}^{7}$ and $\mathbf{L}^{\mathbf{8}[29]}$ were prepared according to the literature methods. All other chemicals were purchased from commercial sources and used without further purification. Caution! Although we have experienced no difficulties with the perchlorate salts, these should be regarded as potentially explosive and handled with care ${ }^{[30]}$.

\subsection{Synthesis of the complexes}

\subsubsection{General procedure}

The complexes were prepared refluxing overnight a solution of the ligand $(0.2 \mathrm{mmol})$ and sodium perchlorate monohydrate (potassium perchlorate to prepare the potassium complexes) $(0.2 \mathrm{mmol})$ in $15 \mathrm{~mL}$ or $25 \mathrm{~mL}$ of ethanol. The solution was then filtered while hot and the precipitate formed after cooling was isolated by filtration and washed with diethyl ether. If no precipitate was formed the volume of the solution was reduced to one half in a rotary evaporator and the resulting solid was isolated by filtration. 

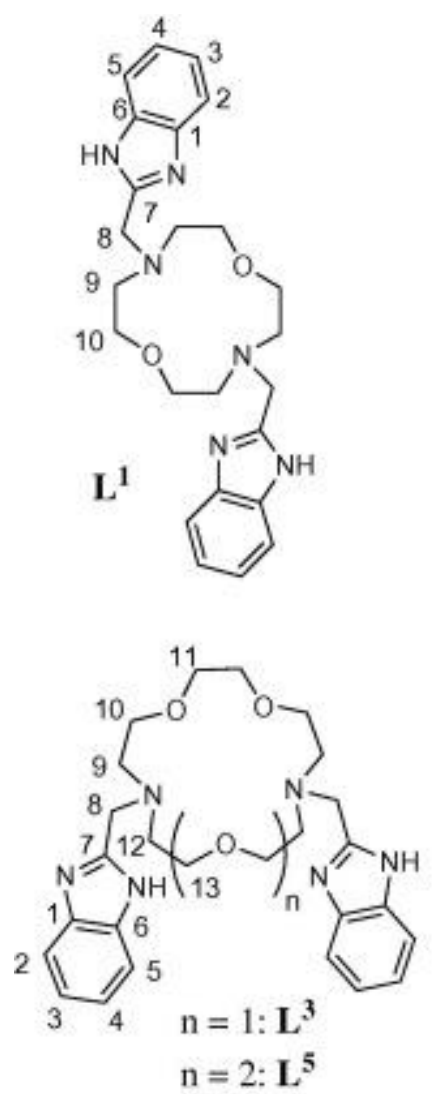
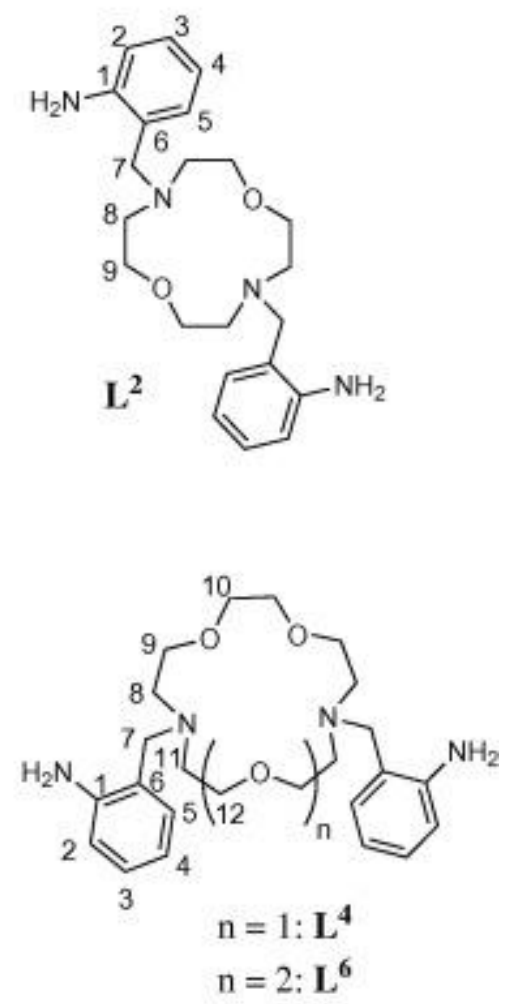

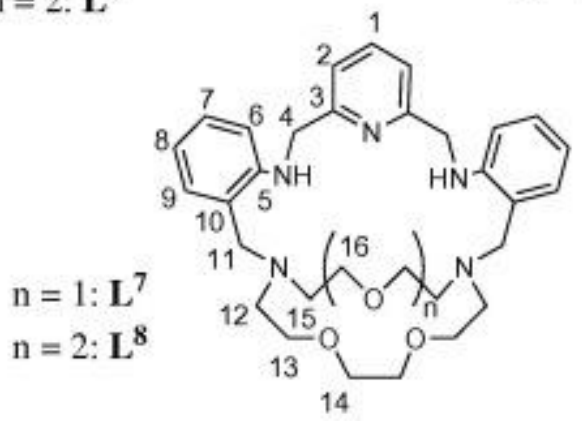

Scheme 1. Structural formula of the ligands studied in this paper including the numbering scheme used for NMR spectroscopy.

\subsection{Experimental data}

The quantities used in each case, and the characterization of the complexes are described in sections 2.3.12.3.8.

\subsection{1. $\left[\mathrm{Na}\left(\mathrm{L}^{1}\right)\right]\left(\mathrm{ClO}_{4}\right)$}

$0.100 \mathrm{~g} \quad(0.230 \mathrm{mmol}) \quad$ of $N, N^{\prime}$-bis(benzimidazole-2-ylmethyl)-1,7-diaza-12-crown-4 and $0.036 \mathrm{~g}$ $(0.253 \mathrm{mmol})$ of $\mathrm{NaClO}_{4} \cdot \mathrm{H}_{2} \mathrm{O}$; Yield: $0.105 \mathrm{~g}(82 \%)$; yellow crystals. Anal. Calc. for $\mathrm{C}_{24} \mathrm{H}_{30} \mathrm{ClN}_{6} \mathrm{NaO}_{6}$ : C, 51.88 (51.75); H, 5.37 (5.43); N, 14.81 (15.09)\%. M.p.: $281.5^{\circ} \mathrm{C}$, decomposition can be observed from $257^{\circ} \mathrm{C} . \Lambda_{\mathrm{M}}$ (acetonitrile, $\left.\quad 10^{-3} \mathrm{M}, \quad 25^{\circ} \mathrm{C}\right): 140 \mathrm{~cm}^{2} \Omega^{-1} \mathrm{~mol}^{-1}$ (electrolyte $\left.1: 1\right)^{[31]}$. MS-FAB ${ }^{+}(3-$ nba): $m / z$ uma (\% BPI): $457.2(100.00)\left[\mathrm{Na}\left(\mathbf{L}^{1}\right)\right]^{+}$. IR (ATR, $\left.\mathrm{cm}^{-1}\right): 1624[v(\mathbf{C}=\mathrm{N})] ; 1533[v(\mathrm{C}=\mathrm{C})] ; 1064$ $\left[v_{\mathrm{a}}(\mathrm{Cl}-\mathrm{O})\right] ; 621\left[\delta_{\mathrm{a}}(\mathrm{O}-\mathrm{Cl}-\mathrm{O})\right] .{ }^{1} \mathrm{H}$ NMR $\left(500 \mathrm{MHz}, \mathrm{CD}_{3} \mathrm{CN}\right): 10.60(\mathrm{~s}, \mathrm{br}, 2 \mathrm{H}) \mathrm{NH} ; 7.53(\mathrm{~s}, \mathrm{br}, 2 \mathrm{H})$ and 7.51 (s, br, 2H) H2, H5; 7.25 (s, br, 2H) H3; 7.14 (s, br, 2H) H4; 3.98 (s, 4H) H8; 3.65 (d, 8H) H10; 2.94 (s, br, 4H) H9 equatorial; 2.61 (s, br, 4H) H9 axial. ${ }^{13} \mathrm{C}$ NMR $\left(125.8 \mathrm{MHz}, \mathrm{CD}_{3} \mathrm{CN}\right): 155.16 \mathrm{C} 7 ; 143.72 \mathrm{C} 6 ; 134.94$ 
C1; 123.76 C3; 122.94 C4; $119.61 \mathrm{C} 5 ; 112.47$ C2; 66.38 C10; 53.16 C8; 52.62 C9. X-ray quality single crystals were obtained after cooling the reaction solution in the refrigerator.

\subsection{2. $\left[\mathrm{Na}\left(\mathrm{L}^{2}\right)\right]\left(\mathrm{ClO}_{4}\right)$}

$0.100 \mathrm{~g} \quad(0.230 \mathrm{mmol})$ of $N, N^{\prime}$-bis(2-aminobenzyl)-1,7-diaza-12-crown-4 and $0.036 \mathrm{~g} \quad(0.253 \mathrm{mmol})$ of $\mathrm{NaClO}_{4} \cdot \mathrm{H}_{2} \mathrm{O}$; Yield: $0.066 \mathrm{~g}(50 \%)$; pale yellow crystals. Anal. Calc. for $\mathrm{C}_{22} \mathrm{H}_{32} \mathrm{ClN}_{4} \mathrm{O}_{6} \mathrm{Na}: \mathrm{C}, 52.2$ (52.1); $\mathrm{H}, 6.1$ (6.4); N, 10.9 (11.1)\%. M.p.: $234{ }^{\circ} \mathrm{C} . \Lambda_{\mathrm{M}}\left(\right.$ acetonitrile, $\left.10^{-3} \mathrm{M}, 25^{\circ} \mathrm{C}\right)=161 \mathrm{~cm}^{2} \Omega^{-1} \mathrm{~mol}^{-1}(1: 1$ electrolyte) ${ }^{[31]}$. MS-ESI-TOF $\mathrm{m} / z$ uma (\%BPI): $407.2(100.00)\left[\mathrm{Na}\left(\mathbf{L}^{2}\right)\right]^{+}$. IR (ATR, $\left.\mathrm{cm}^{-1}\right): 3387\left[v_{\text {as }}\left(\mathrm{NH}_{2}\right)\right]$; $3309\left[v_{\mathrm{s}}\left(\mathrm{NH}_{2}\right)\right] ; 1612\left[\delta\left(\mathrm{NH}_{2}\right)\right] ; 1069\left[v_{\mathrm{a}}(\mathrm{Cl}-\mathrm{O})\right] ; 621\left[\delta_{\mathrm{a}}(\mathrm{O}-\mathrm{Cl}-\mathrm{O})\right] .{ }^{1} \mathrm{H}$ NMR: $6.96(\mathrm{dd}, 2 \mathrm{H}) \mathrm{H} 2 ; 7.19(\mathrm{td}$, 2H) H3; $6.82(\mathrm{td}, 2 \mathrm{H}) \mathrm{H} 4 ; 7.08(\mathrm{dd}, 2 \mathrm{H}) \mathrm{H} 5 ; 3.52(\mathrm{~s}, 4 \mathrm{H}) \mathrm{H} 7 ; 2.59$ (t, 4H) H8; 3.44 (t, 8H) H9; 4.14 (s, br, $4 \mathrm{H}) \mathrm{NH}_{2} .{ }^{13} \mathrm{C}$ NMR $\left(125.8 \mathrm{MHz}, \mathrm{CD}_{3} \mathrm{CN}\right): 146.29 \mathrm{C} 1 ; 118.85 \mathrm{C} 2 ; 130.14 \mathrm{C} 3 ; 120.78 \mathrm{C} 4 ; 133.21 \mathrm{C} 5 ; 125.23$ C6; 59.19 C7; 52.74 C8; 66.97 C9.

\subsection{3. $\left[\mathrm{Na}\left(\mathrm{L}^{3}\right)\right]\left(\mathrm{ClO}_{4}\right)$}

$0.100 \mathrm{~g} \quad(0.209 \mathrm{mmol}) \quad$ of $N, N^{\prime}$-bis(benzimidazole-2-ylmethyl)-1,10-diaza-15-crown-5 and $0.032 \mathrm{~g}$ $(0.23 \mathrm{mmol})$ of $\mathrm{NaClO}_{4} \cdot \mathrm{H}_{2} \mathrm{O}$. In this case, after cooling to room temperature, the solution was filtered and the solvent was completely eliminated in a rotary evaporator. The oil formed was transformed into a solid by agitation with diethyl ether, the solid was filtered and solved in chloroform to eliminate any excess of sodium perchlorate by filtration, and then the solvent was completely eliminated in a rotary evaporator. Yield: $0.067 \mathrm{~g}$ (54\%); light brown solid. Anal. Calc. for $\mathrm{C}_{26} \mathrm{H}_{34} \mathrm{ClN}_{6} \mathrm{NaO}_{7}$ : C, 52.48 (51.96); H, 5.60 (5.70); $\mathrm{N}, 13.80$ (13.98)\%. M.p.: $235.5^{\circ} \mathrm{C}$, decomposition can be observed from $210^{\circ} \mathrm{C} . \Lambda_{\mathrm{M}}$ (acetonitrile, $10^{-3} \mathrm{M}$, $\left.25^{\circ} \mathrm{C}\right): 132 \mathrm{~cm}^{2} \Omega^{-1} \mathrm{~mol}^{-1}$ (electrolyte $\left.1: 1\right)^{[31]}$. $\mathrm{MS}-\mathrm{FAB}^{+}(3-\mathrm{nba}): \mathrm{m} / \mathrm{z}$ uma $(\%$ BPI): $501.2 \quad$ (100.00) $\left[\mathrm{Na}\left(\mathbf{L}^{3}\right)\right]^{+} . \mathrm{IR}\left(\mathrm{ATR}, \mathrm{cm}^{-1}\right): 1622[v(\mathrm{C}=\mathrm{N})] ; 1537[v(\mathrm{C}=\mathrm{C})] ; 1065\left[v_{\mathrm{a}}(\mathrm{Cl}-\mathrm{O})\right] ; 621\left[\delta_{\mathrm{a}}(\mathrm{O}-\mathrm{Cl}-\mathrm{O})\right] .{ }^{1} \mathrm{H}$ NMR (500 MHz, CD $\left.{ }_{3} \mathrm{CN}\right): 7.28(\mathrm{~m}, 4 \mathrm{H}) \mathrm{H} 2, \mathrm{H} 5 ; 7.06$ (s, br, 4H) H3, H4; 4.00 (s, 4H) H8; $3.52(\mathrm{~s}, 4 \mathrm{H}) \mathrm{H} 11 ; 3.44$ (m, 8H) H10, H13; 2.80 (s, br, 8H) H9, H12. ${ }^{13} \mathrm{C}$ NMR (125.8 MHz, $\left.\mathrm{CD}_{3} \mathrm{CN}\right): 154.97 \mathrm{C} 7 ; 123.15 \mathrm{C} 2, \mathrm{C} 3$, C4, C5; 69.92 C11; 68.12 C13; 68.02 C10; 57.07 C9; 55.83 C12; 54.57 C8.

\subsection{4. $\left[\mathrm{Na}\left(\mathrm{L}^{4}\right)\right](\mathrm{ClO} 4)$}

$0.100 \mathrm{~g}(0.234 \mathrm{mmol})$ of $N, N^{\prime}$-bis(2-aminobenzyl)-1,10-diaza-15-crown-5 $\left(\mathbf{L}^{4}\right)$ and $0.033 \mathrm{~g}(0.235 \mathrm{mmol})$ of sodium perchlorate monohydrate. Yield: $0.105 \mathrm{~g}(82 \%)$; white precipitate. Anal. Calc. for $\mathrm{C}_{24} \mathrm{H}_{36} \mathrm{ClN}_{4} \mathrm{O}_{7} \mathrm{Na}$ : C, $52.1 \quad(52.3) ; \quad \mathrm{H}, \quad 6.5 \quad(6.6) ; \quad \mathrm{N}, \quad 10.3 \quad(10.2) \%$. $\quad$ M.p.: $173{ }^{\circ} \mathrm{C} . \Lambda_{\mathrm{M}}$ (acetonitrile, $10^{-3} \mathrm{M}$, $\left.25^{\circ} \mathrm{C}\right)=158 \mathrm{~cm}^{2} \Omega^{-1} \mathrm{~mol}^{-1}(1: 1 \text { electrolyte })^{[31]}$. MS-ESI-TOF: $\mathrm{m} / \mathrm{z}$ uma (\% BPI) 451 (100) $\left[\mathrm{Na}\left(\mathbf{L}^{4}\right)\right]^{+}, 429$ (4) $\left[\mathrm{HL}^{4}\right]^{+}$. IR $\left(\mathrm{ATR}, \mathrm{cm}^{-1}\right): 3413\left[v_{\mathrm{as}}\left(\mathrm{NH}_{2}\right)\right] ; 3338\left[v_{\mathrm{s}}\left(\mathrm{NH}_{2}\right)\right] ; 1619\left[\delta\left(\mathrm{NH}_{2}\right)\right] ; 1066\left[v_{\mathrm{a}}(\mathrm{Cl}-\mathrm{O})\right] ; 620\left[\delta_{\mathrm{a}}(\mathrm{O}-\right.$ $\mathrm{Cl}-\mathrm{O})]$. ${ }^{1} \mathrm{H}$ NMR $\left(500 \mathrm{MHz}, \mathrm{CD}_{3} \mathrm{CN}\right): 7.14$ (td, 2H) H3; 7.02 (dd, 2H) H5; 6.74 (m, 4H) H2, H4; 3.79 (s, br, 4H) $\mathrm{NH}_{2} ; 3.50(\mathrm{t}, 4 \mathrm{H}) \mathrm{H} 9 ; 3.49(\mathrm{~s}, 4 \mathrm{H}) \mathrm{H} 10 ; 3.47(\mathrm{t}, 4 \mathrm{H}) \mathrm{H} 12 ; 3.43(\mathrm{~s}, 4 \mathrm{H}) \mathrm{H} 7 ; 2.52(\mathrm{~m}, 8 \mathrm{H}) \mathrm{H} 8, \mathrm{H} 11 .{ }^{13} \mathrm{C}$ NMR $\left(125.8 \mathrm{MHz}, \mathrm{CD}_{3} \mathrm{CN}\right): 146.78 \mathrm{C} 1 ; 133.11 \mathrm{C} 5 ; 129.95 \mathrm{C} 3 ; 124.29 \mathrm{C} 6 ; 120.09 \mathrm{C} 4 ; 118.20 \mathrm{C} 2 ; 69.27$ $\mathrm{C} 10 ; 67.33 \mathrm{C} 9 ; 67.08 \mathrm{C} 12$; $57.20 \mathrm{C} 7 ; 53.68 \mathrm{C} 8$; $53.35 \mathrm{C} 11$. X-ray quality single crystals were obtained by slow diffusion of diethyl ether into a solution of the complex in methanol.

\subsection{5. $\left[\mathrm{Na}\left(\mathrm{L}^{5}\right)\right]\left(\mathrm{ClO}_{4}\right)$}

$0.100 \mathrm{~g} \quad(0.192 \mathrm{mmol}) \quad$ of $N, N^{\prime}$-bis(benzimidazole-2-ylmethyl)-4,13-diaza-18-crown-6 and $0.030 \mathrm{~g}$ (0.211 mmol) of sodium perchlorate monohydrate. Yield: $0.093 \mathrm{~g}, 75 \%$, pale yellow crystals. Anal. Calc. for $\mathrm{C}_{28} \mathrm{H}_{38} \mathrm{ClN}_{6} \mathrm{NaO}_{8}: \mathrm{C}, 52.28$ (52.13); H, 6.17 (5.94); N, 12.82 (13.03)\%. M.p.: $225.6{ }^{\circ} \mathrm{C}$, decomposition can be observed from $198^{\circ} \mathrm{C} . \Lambda_{\mathrm{M}}$ (acetonitrile, $10^{-3} \mathrm{M}, 25^{\circ} \mathrm{C}$ ): $131 \mathrm{~cm}^{2} \Omega^{-1} \mathrm{~mol}^{-1}$ (electrolyte $\left.1: 1\right)^{[31]}$. MS$\mathrm{FAB}^{+}$(3-nba): $m / z$ uma (\% BPI): $545.3(100.00)\left[\mathrm{Na}\left(\mathbf{L}^{5}\right)\right]^{+}$. IR $\left(\mathrm{ATR}, \mathrm{cm}^{-1}\right): 1623[v(\mathrm{C}=\mathrm{N})] ; 1070\left[v_{\mathrm{a}}(\mathrm{Cl}-\right.$ O)]; $621\left[\delta_{\mathrm{a}}(\mathrm{O}-\mathrm{Cl}-\mathrm{O})\right] .{ }^{1} \mathrm{H}$ NMR $\left(500 \mathrm{MHz}, \mathrm{CD}_{3} \mathrm{CN}\right): 10.40(\mathrm{~s}, \mathrm{br}, 2 \mathrm{H}) \mathrm{NH} ; 7.43(\mathrm{~s}, \mathrm{br}, 4 \mathrm{H}) \mathrm{H} 2, \mathrm{H} 5 ; 7.12$ (s, br, 4H) H3, H4; 3.95 (s, 4H) H8; 3.57 (t, 8H) H10; 3.36 (s, 8H) H11; 2.89 (t, 8H) H9. ${ }^{13} \mathrm{C}$ NMR (125.8 MHz, 
$\mathrm{CD}_{3} \mathrm{CN}$ ): $154.65 \mathrm{C} 7$; $122.91 \mathrm{C} 3, \mathrm{C} 4 ; 112.00 \mathrm{C} 2, \mathrm{C} 5$; $69.77 \mathrm{C} 11$; $68.29 \mathrm{C} 10$; $56.05 \mathrm{C} 9 ; 53.35 \mathrm{C} 8$. X-ray quality single crystals were obtained after slow cooling of the mother solution in the refrigerator.

\subsection{6. $\left[\mathrm{Na}\left(\mathrm{L}^{6}\right)\right](\mathrm{ClO} 4)$}

$0.100 \mathrm{~g}$ ( $0.212 \mathrm{mmol})$ of $N, N^{\prime}$-bis(2-aminobenzyl)-4,13-diaza-18-crown-6 and $0.030 \mathrm{~g}$ (0.214 mmol) of sodium perchlorate monohydrate. Yield: $0.105 \mathrm{~g}$ (83\%); white precipitate. Anal. Calc. for $\mathrm{C}_{26} \mathrm{H}_{40} \mathrm{ClN}_{4} \mathrm{O}_{8} \mathrm{Na}$ : C, 52.5 (52.5); H, 6.4 (6.8); N, 9.5 (9.4)\%. M.p.: $246{ }^{\circ} \mathrm{C}$ (decomp.). $\Lambda_{\mathrm{M}}$ (acetonitrile, $10^{-3} \mathrm{M}$, $\left.25^{\circ} \mathrm{C}\right)=130 \mathrm{~cm}^{2} \Omega^{-1} \mathrm{~mol}^{-1}(1: 1 \text { electrolyte })^{[31]}$. MS-ESI-TOF: $m / z$ uma (\% BPI) 473 (100) $\left[\mathrm{HL}^{6}\right]^{+}$. IR (ATR, $\left.\mathrm{cm}^{-1}\right): 3406\left[v_{\mathrm{as}}\left(\mathrm{NH}_{2}\right)\right] ; 3337\left[v_{\mathrm{s}}\left(\mathrm{NH}_{2}\right)\right] ; 1623\left[\delta\left(\mathrm{NH}_{2}\right)\right] ; 1070\left[v_{\mathrm{a}}(\mathrm{Cl}-\mathrm{O})\right] ; 621\left[\delta_{\mathrm{a}}(\mathrm{O}-\mathrm{Cl}-\mathrm{O})\right] .{ }^{1} \mathrm{H}$ NMR (500 MHz, $\left.\mathrm{CD}_{3} \mathrm{CN}\right): 4.10$ (s, br, 4H) $\mathrm{NH}_{2} ; 6.72(\mathrm{~m}, 4 \mathrm{H}) \mathrm{H} 2, \mathrm{H} 4 ; 7.07$ (m, 4H) H3, H5; 3.50 (s, 4H) H7; 2.65 (t, 8H) H8; 3.57 (t, 8H) H9; 3.19 (s, 4H) H10. $\left.{ }^{13} \mathrm{C} \mathrm{NMR} \mathrm{(125.8} \mathrm{MHz,} \mathrm{CD}_{3} \mathrm{CN}\right): 129.59 \mathrm{C} 3 ; 132.74 \mathrm{C} 5$; $124.52 \mathrm{C} 6 ; 57.19 \mathrm{C} 7 ; 53.94 \mathrm{C} 8 ; 68.15 \mathrm{C} 9 ; 69.20 \mathrm{C} 10$. Colorless X-ray quality single crystals were obtained by slow diffusion of diethyl ether into a solution of the complex in methanol.

\subsection{7. $\left[K\left(L^{6}\right)\right](C l O 4)$}

$0.100 \mathrm{~g}(0.212 \mathrm{mmol})$ of $N, N^{\prime}$-bis(2-aminobenzyl)-4,13-diaza-18-crown-6 and $0.029 \mathrm{~g}(0.209 \mathrm{mmol})$ of potassium perchlorate monohydrate. Yield: $0.102 \mathrm{~g}$ (78\%), white precipitate. Anal. Calc. for $\mathrm{C}_{26} \mathrm{H}_{40} \mathrm{ClN}_{4} \mathrm{O}_{8} \mathrm{~K}:$ C: 50.4 (51.1); H: 6.5 (6.6);N: 9.0 (9.2)\%. M.p.: $172{ }^{\circ} \mathrm{C}$ (decomp.). $\Lambda_{\mathrm{M}}$ (acetonitrile, $\left.10^{-3} \mathrm{M}, 25^{\circ} \mathrm{C}\right)=180 \mathrm{~cm}^{2} \Omega^{-1} \mathrm{~mol}^{-1}(1: 1 \text { electrolyte })^{[31]}$. MS-ESI-TOF: $\mathrm{m} / z$ uma (\% BPI) $511(7)\left[\mathrm{K}\left(\mathbf{L}^{6}\right)\right]^{+}$, $473(100)\left[\mathrm{HL}^{6}\right]^{+}$. IR $\left(\mathrm{ATR}, \mathrm{cm}^{-1}\right): 3420\left[v_{\mathrm{as}}\left(\mathrm{NH}_{2}\right)\right] ; 3346\left[v_{\mathrm{s}}\left(\mathrm{NH}_{2}\right)\right] ; 1630\left[\delta\left(\mathrm{NH}_{2}\right)\right] ; 1075\left[v_{\mathrm{a}}(\mathrm{Cl}-\mathrm{O})\right] ; 623$ $\left[\delta_{\mathrm{a}}(\mathrm{O}-\mathrm{Cl}-\mathrm{O})\right] .{ }^{1} \mathrm{H}$ NMR $\left(500 \mathrm{MHz}, \mathrm{CD}_{3} \mathrm{CN}\right): 4.37$ (s, br, 4H) NH $\mathrm{NH}_{2} ; 6.71(\mathrm{dd}, 2 \mathrm{H}) \mathrm{H} 2 ; 6.67(\mathrm{td}, 2 \mathrm{H}) \mathrm{H} 4 ; 7.10$ $(\mathrm{td}, 2 \mathrm{H}) \mathrm{H} 3 ; 7.03$ (dd, 2H) H5; $3.06(\mathrm{~s}, 4 \mathrm{H}) \mathrm{H} 7 ; 2.64(\mathrm{t}, 8 \mathrm{H}) \mathrm{H} 8 ; 3.54(\mathrm{t}, 8 \mathrm{H}) \mathrm{H} 9 ; 3.38(\mathrm{~s}, 4 \mathrm{H}) \mathrm{H} 10 .{ }^{13} \mathrm{C}$ NMR $\left(125.8 \mathrm{MHz}, \mathrm{CD}_{3} \mathrm{CN}\right): 147.66 \mathrm{C} 1 ; 117.11 \mathrm{C} 2 ; 129.65 \mathrm{C} 3 ; 118.74 \mathrm{C} 4 ; 132.57 \mathrm{C} 5 ; 123.85 \mathrm{C} 6$; $57.33 \mathrm{C} 7$; $55.57 \mathrm{C} 8$; $68.63 \mathrm{C} 9 ; 70.46 \mathrm{C} 10$. X-ray quality single crystals were obtained by slow evaporation of the mother solution.

\subsection{8. $\left[\mathrm{Na}\left(\mathrm{L}^{7}\right)\right]\left(\mathrm{ClO}_{4}\right)$}

$0.050 \mathrm{~g}(0.094 \mathrm{mmol})$ of $\mathbf{L}^{7}$ and $0.0132 \mathrm{~g}$, $(0.094 \mathrm{mmol})$ of sodium perchlorate monohydrate. Yield: $0.047 \mathrm{~g}$ (76\%), yellow solid. Anal. Calc. for $\mathrm{C}_{31} \mathrm{H}_{41} \mathrm{ClN}_{5} \mathrm{NaO}_{7}$ : C, 56.98 (56.92); H, 6.05 (6.32); N, 10.41 (10.71)\%. M.p.: $\quad 243.7^{\circ} \mathrm{C}$ (decomposition can be observed from $160{ }^{\circ} \mathrm{C}$ ). $\Lambda_{\mathrm{M}}$ (acetonitrile, $10^{-3} \mathrm{M}$, $\left.25^{\circ} \mathrm{C}\right)=163 \mathrm{~cm}^{2} \Omega^{-1} \mathrm{~mol}^{-1}(1: 1 \text { electrolyte })^{[31]}$. $\operatorname{MS}^{-F_{A B}}{ }^{+}$(3-nba): $\mathrm{m} / z$ uma $(\%$ BPI): $554.3 \quad$ (100.00) $\left[\mathrm{Na}\left(\mathbf{L}^{7}\right)\right]^{+}$. IR $\left(\mathrm{ATR}, \mathrm{cm}^{-1}\right): 3338[v(\mathrm{~N}-\mathrm{H})] ; 1600-1440[v(\mathrm{Ph} / \mathrm{Py})] ; 1077\left[v_{\mathrm{a}}(\mathrm{Cl}-\mathrm{O})\right] ; 754[\pi(\mathrm{C}-\mathrm{H})] ; 620$ $\left[\delta_{\mathrm{a}}(\mathrm{O}-\mathrm{Cl}-\mathrm{O})\right] .{ }^{1} \mathrm{H}$ NMR $\left(500 \mathrm{MHz}, \mathrm{CD}_{3} \mathrm{CN}\right): 7.81(\mathrm{t}, 1 \mathrm{H}) \mathrm{H} 1 ; 7.46(\mathrm{~d}, 2 \mathrm{H}) \mathrm{H} 2 ; 7.10(\mathrm{td}, 2 \mathrm{H}) \mathrm{H} 7 ; 7.04(\mathrm{dd}$, 2H) H9; 6.64 (td, 2H) H8; 6.61 (d, 2H) H6; 6.11 (s, br, 2H) NH; 4.35 (s, 4H) H4; 3.87 (t, 2H); 3.71 (d, 2H) H11; 3.64-3.36 (m, 12H); 2.94 (t, 2H); $2.67(\mathrm{~d}, 4 \mathrm{H}) ; 2.48$ (d, 2H). Signals for protons H12, H13, H14, H15 and $\mathrm{H} 16$ can't be unequivocally assigned. ${ }^{13} \mathrm{C}$ NMR $\left(125.8 \mathrm{MHz}, \mathrm{CD}_{3} \mathrm{CN}\right): 161.27 \mathrm{C} 3 ; 148.57 \mathrm{C} 5 ; 138.90$ C1; 131.74 C9; 129.75 C7; 124.13 C10; 123.24 C2; 118.27 C8; 112.26 C6; 68.90; 68.68; 67.82; 58.15 C11; 55.33; 53.55; $50.77 \mathrm{C} 4$. Signals for carbons $\mathrm{C} 12, \mathrm{C} 13, \mathrm{C} 14, \mathrm{C} 15$ and $\mathrm{C} 16$ can not be unequivocally assigned. $\mathrm{X}$-ray quality single crystals were obtained by slow evaporation of an acetonitrile solution of the complex.

\section{4. $\underline{\text { Measurements }}$}

Elemental analyses were carried out on a Carlo Erba 1108 elemental analyzer. FAB mass spectra were recorded on a Fisons Quatro mass spectrometer with a Cs ion gun using 3-nitrobenzyl alcohol as matrix and ESI-TOF mass spectra were recorded using a LC-Q-q-TOF Applied Biosystems QSTAR Elite spectrometer in the positive mode. ${ }^{1} \mathrm{H}$ and ${ }^{13} \mathrm{C}$ NMR spectra were run on a Bruker Avance 500 using acetonitrile- $\mathrm{d}_{3}$ as solvent. IR spectra were recorded using a Bruker Vector22 spectrophotometer equipped with a Golden Gate Attenuated Total Reflectance (ATR) accessory (Specac). Conductivity measurements were carried out with a Crison Micro CM 2201 conductivimeter using $\mathrm{ca} \cdot 10^{-3} \mathrm{M}$ solutions of the complexes in acetonitrile. 


\subsection{Spectrophotometric titrations}

UV-Vis spectra were recorded with a Perkin-Elmer Lambda 900 spectrophotometer, with quartz cells (path length: $1 \mathrm{~cm}$ ). The cell holder was thermostated at $25.0^{\circ} \mathrm{C}$, through circulating water. The formation of the $\mathrm{Na}^{+}$complexes was monitored by using spectrophotometric titrations at $25^{\circ} \mathrm{C}$ on $\mathrm{ca} .10^{-4} \mathrm{M}$ solutions of the corresponding ligand in $\mathrm{CH}_{3} \mathrm{CN}$ (polarographic grade). Typically, aliquots of a fresh standard solution of sodium perchlorate in the same solvent $(c a .0 .01-0.1 \mathrm{M})$ were added and the UV-Vis spectra of the samples were recorded. All spectrophotometric titration curves were fitted with the hyperquadprogram ${ }^{[32]}$. Binding constants were obtained by using a simultaneous fit of the UV-Vis absorption spectral changes at 8-28 selected wavelengths in the range $225-320 \mathrm{~nm}$. A minimum of 19-28 absorbance data points at each of these wavelengths was used.

\subsection{X-ray crystallography}

Three dimensional X-ray data were collected on a Bruker SMART $1000 \mathrm{CCD}$ for complexes $\left[\mathrm{Na}\left(\mathbf{L}^{6}\right)\right]\left(\mathrm{ClO}_{4}\right)$ and $\left[\mathrm{Na}\left(\mathbf{L}^{7}\right)\right]\left(\mathrm{ClO}_{4}\right)$ and on a BRUKER-NONIUS X8 APEX KAPPA CCD for $\left[\mathrm{Na}\left(\mathbf{L}^{1}\right)\right]\left(\mathrm{ClO}_{4}\right)$, $\left[\mathrm{Na}\left(\mathbf{L}^{4}\right)\right]\left(\mathrm{ClO}_{4}\right),\left[\mathrm{Na}\left(\mathbf{L}^{5}\right)\right]\left(\mathrm{ClO}_{4}\right)$ and $\left[\mathrm{K}\left(\mathbf{L}^{6}\right)\right]\left(\mathrm{ClO}_{4}\right)$. Data were corrected for Lorentz and polarization effects and for absorption by semiempirical methods ${ }^{[33]}$ based on symmetry-equivalent reflections. Complex scattering factors were taken from the program shelx $97^{[34]}$ running under the WinGX program system ${ }^{[35]}$ as implemented on a Pentium ${ }^{\circledR}$ computer. Two of the structures were solved by direct methods (shelxs97 for $\left[\mathrm{K}\left(\mathbf{L}^{6}\right)\right]\left(\mathrm{ClO}_{4}\right)$ and SUPERFLIP ${ }^{[36]}$ for $\left.\left[\mathrm{Na}\left(\mathbf{L}^{4}\right)\right]\left(\mathrm{ClO}_{4}\right)\right)$ and the other four structures were solved by Patterson methods (DIRDIF99 ${ }^{[37]}$ for $\left[\mathrm{Na}\left(\mathbf{L}^{6}\right)\right]\left(\mathrm{ClO}_{4}\right)$, DIRDIF2008 ${ }^{[38]}$ for $\left[\mathrm{Na}\left(\mathbf{L}^{5}\right)\right]\left(\mathrm{ClO}_{4}\right)$ and SHELXS97for $\left[\mathrm{Na}\left(\mathbf{L}^{\mathbf{1}}\right)\right]\left(\mathrm{ClO}_{4}\right)$ and $\left.\left[\mathrm{Na}\left(\mathbf{L}^{7}\right)\right]\left(\mathrm{ClO}_{4}\right)\right)$. All the structures were refined by full-matrix least-squares on $F^{2}$ and the hydrogen atoms were included in calculated positions and refined in riding mode except the aniline hydrogen atoms in $\left[\mathrm{K}\left(\mathbf{L}^{6}\right)\right]\left(\mathrm{ClO}_{4}\right)$, which were located in an electron density map and refined freely.

One pendant arm of the ligand in $\left[\mathrm{Na}\left(\mathbf{L}^{4}\right)\right]^{+}$presents conformational disorder in the crystal measured that has been modeled in two locations and the corresponding atom site occupations refined. The final value for the population parameter is 60(4)\% for the positions labeled as A. Many of the perchlorate anions in the crystals are disordered, for $\left[\mathrm{Na}\left(\mathbf{L}^{7}\right)\right]\left(\mathrm{ClO}_{4}\right)$ it shows positional disorder that was modeled in two locations with refined atom site occupation of 58(3)\% for atoms labeled with A. The perchlorate groups found in crystals of $\left[\mathrm{Na}\left(\mathbf{L}^{5}\right)\right]\left(\mathrm{ClO}_{4}\right),\left[\mathrm{Na}\left(\mathbf{L}^{6}\right)\right]\left(\mathrm{ClO}_{4}\right)$ and $\left[\mathrm{K}\left(\mathbf{L}^{6}\right)\right]\left(\mathrm{ClO}_{4}\right)$ were sitting on an inversion center.

Refinement converged with anisotropic displacement parameters for all non-hydrogen atoms in every case. Crystal data and details on data collection and refinement are summarized in Table 1.

It is important to remark that the crystal of $\left[\mathrm{Na}\left(\mathbf{L}^{7}\right)\right]\left(\mathrm{ClO}_{4}\right)$ diffracts weakly and the data are of low quality, that generates an A level alert in the checkCIF/PLATON report. Although we know the low quality of the data, we have decided to include this crystal structure due to its interest for comparison. 
Table 1. Crystal data and structure refinement for $\mathrm{Na}^{+}$and $\mathrm{K}^{+}$complexes.

\begin{tabular}{|c|c|c|c|c|c|c|}
\hline & {$\left[\mathrm{NaL}^{1}\right]\left(\mathrm{ClO}_{4}\right)$} & {$\left[\mathrm{NaL}^{4}\right]\left(\mathrm{ClO}_{4}\right)$} & {$\left[\mathrm{NaL}^{5}\right]\left(\mathrm{ClO}_{4}\right)$} & {$\left[\mathrm{NaL}^{6}\right]\left(\mathrm{ClO}_{4}\right)$} & {$\left[\mathrm{KL}^{6}\right]\left(\mathrm{ClO}_{4}\right)$} & {$\left[\mathrm{NaL}^{7}\right]\left(\mathrm{ClO}_{4}\right)$} \\
\hline Empirical Formula & $\mathrm{C}_{24} \mathrm{H}_{30} \mathrm{ClN}_{6} \mathrm{NaO}_{6}$ & $\mathrm{C}_{49} \mathrm{H}_{76} \mathrm{Cl}_{2} \mathrm{~N}_{8} \mathrm{Na}_{2} \mathrm{O}_{15}$ & $\mathrm{C}_{28} \mathrm{H}_{38} \mathrm{ClN}_{6} \mathrm{NaO}_{8}$ & $\mathrm{C}_{26} \mathrm{H}_{40} \mathrm{ClN}_{4} \mathrm{NaO}_{8}$ & $\mathrm{C}_{26} \mathrm{H}_{40} \mathrm{ClKN}_{4} \mathrm{O}_{8}$ & $\mathrm{C}_{31} \mathrm{H}_{41} \mathrm{ClN}_{5} \mathrm{NaO}_{7}$ \\
\hline Molecular weight & 556.98 & 1134.06 & 645.08 & 595.06 & 611.17 & 654.13 \\
\hline Temperature (K) & $100.0(2)$ & $100(2)$ & $100.0(2)$ & $120.0(2)$ & $100.0(2)$ & 293(2) \\
\hline Wavelength $(\AA)$ & 0.71073 & 0.71073 & 0.71073 & 0.71073 & 0.71073 & 0.71073 \\
\hline Crystal system & monoclinic & monoclinic & triclinic & triclinic & triclinic & monoclinic \\
\hline Space group & $P 2_{1} / n$ & $P 2_{1} / n$ & $\mathrm{P} \overline{1}$ & $\mathrm{P} \overline{1}$ & $\mathrm{P} \overline{1}$ & $P 2_{1} / n$ \\
\hline$a(\AA)$ & $14.5614(3)$ & $11.5739(3)$ & $8.9268(6)$ & $8.707(2)$ & $8.4370(7)$ & $15.1569(4)$ \\
\hline$b(\AA)$ & $12.1744(2)$ & $20.0081(5)$ & $9.6726(6)$ & $9.440(2)$ & $9.5611(7)$ & $11.7113(5)$ \\
\hline$c(\AA)$ & $14.6819(3)$ & $11.7766(3)$ & $9.8972(6)$ & $9.689(2)$ & $9.9870(8)$ & 19.0977(7) \\
\hline$\alpha\left(^{\circ}\right)$ & 90 & 90 & $77.166(4)$ & $109.830(3)$ & 110.121(4) & 90 \\
\hline$\beta\left(\left(^{\circ}\right)\right.$ & $104.253(1)$ & $94.629(3)$ & $72.601(4)$ & $91.254(3)$ & $91.661(5)$ & 108.391(2) \\
\hline$\gamma\left({ }^{\circ}\right)$ & 90 & 90 & $68.850(4)$ & $108.922(3)$ & $107.410(5)$ & 90 \\
\hline$V\left(\AA^{3}\right)$ & 2522.63(8) & 2718.2(1) & $754.25(8)$ & $700.9(2)$ & $713.9(1)$ & $3216.8(2)$ \\
\hline$F\left(\begin{array}{lll}0 & 0 & 0\end{array}\right)$ & 1168 & 1204 & 340 & 316 & 324 & 1384 \\
\hline$Z$ & 4 & 2 & 1 & 1 & 1 & 4 \\
\hline Calculated density $\left(\mathrm{g} \mathrm{cm}^{-3}\right)$ & 1.467 & 1.386 & 1.420 & 1.410 & 1.422 & 1.351 \\
\hline Absorption coefficient $\left(\mathrm{mm}^{-1}\right)$ & 0.222 & 0.209 & 0.201 & 0.208 & 0.335 & 0.187 \\
\hline$\theta\left(^{\circ}\right)$ & $2.89-28.38$ & $2.58-28.31$ & $2.28-28.37$ & $2.26-26.40$ & $2.40-28.36$ & $2.07-28.30$ \\
\hline$R_{\text {int }}$ & 0.0351 & 0.0316 & 0.0259 & 0.0337 & 0.0252 & 0.1354 \\
\hline Reflections measured & 25401 & 28331 & 13739 & 2852 & 12613 & 19909 \\
\hline Reflections observed & 5014 & 5327 & 3720 & 1970 & 3000 & 2300 \\
\hline Goodness of fit (GOF) on $F^{2}$ & 1.024 & 1.030 & 1.054 & 1.049 & 1.033 & 0.973 \\
\hline$R_{1}^{\mathrm{a}}$ & 0.0361 & 0.0468 & 0.0430 & 0.0466 & 0.0577 & 0.0902 \\
\hline$w R_{2}$ (all data) ${ }^{\mathrm{b}}$ & 0.0936 & 0.1269 & 0.1068 & 0.1212 & 0.159 & 0.2109 \\
\hline Largest differences peak and hole $\left(\mathrm{e} \AA^{-3}\right)$ & 0.361 and -0.457 & 0.852 and -0.792 & 0.494 and -1.095 & 0.583 and -0.411 & 1.176 and -0.634 & 0.283 and -0.229 \\
\hline
\end{tabular}

${ }^{\mathrm{a}} R_{1}=\sum\left\|\mathrm{F}_{\mathrm{o}}|-| F_{\mathrm{c}}\right\| / \sum\left|F_{\mathrm{o}}\right| \cdot{ }^{\mathrm{b}} w R_{2}=\left\{\sum\left[w\left(\|\left. F_{\mathrm{o}}{ }^{2}|-| F_{\mathrm{c}}\right|^{2} \mid\right)^{2}\right] \mid / \sum\left[w\left(\mathrm{~F}_{\mathrm{o}}{ }^{4}\right)\right]\right\}^{1 / 2}$. 


\section{Results and discussion}

\subsection{Spectroscopic characterization}

All the complexes prepared were fully characterized by elemental analysis, conductimetric measurements, IR and NMR spectroscopies and mass spectrometry. The elemental analyses agree with the formulas proposed in the experimental part, the mass spectrometry data also confirms the formation of the complexes as the ion $\left[\mathrm{Na}\left(\mathbf{L}^{\mathbf{n}}\right)\right]^{+}$can be observed in every spectrum except that of $\left[\mathrm{Na}\left(\mathbf{L}^{6}\right)\right]^{+}$. The molar conductivity values, as measured in $\sim 10^{-3} \mathrm{M}$ acetonitrile solutions of the complexes, fall in the range generally accepted for 1:1 electrolytes in this solvent $\left(120-160 \mathrm{~cm}^{2} \Omega^{-1} \mathrm{~mol}^{-1}\right)$, suggesting that the perchlorate anionsare not coordinated to the metal ion in solution .

The IR spectra of the complexes are not very informative. Those containing anilinefunctional groups display bands at $c a .3400$ and $3320 \mathrm{~cm}^{-1}$ corresponding respectively to the $v_{\text {as }}\left(\mathrm{NH}_{2}\right)$ and $v_{\mathrm{s}}\left(\mathrm{NH}_{2}\right)$ stretching modes of the coordinated amine groups. The IR spectrum of the complex of $\mathbf{L}^{7}$ displays only one band at $3338 \mathrm{~cm}^{-1}$ due to the $v(\mathrm{~N}-\mathrm{H})$ mode, whereas the IR spectra of $\mathbf{L}^{1}, \mathbf{L}^{3}$ and $\mathbf{L}^{5}$ complexes show a band at $c a$. $1530 \mathrm{~cm}^{-1}$ due to the $v(\mathrm{C}=\mathrm{C})$ stretching frequency of the benzimidazole groups ${ }^{[25]}$. This band is shifted by $3-$ $17 \mathrm{~cm}^{-1}$ to higher wavenumbers with respect to its position in the spectrum of the free ligand, in line with the coordination of the pendant arms to the corresponding metal ion. The spectra also show absorption bands at $c a .1090$ and $625 \mathrm{~cm}^{-1}$ attributable to the asymmetric $v_{\text {as }}(\mathrm{Cl}-\mathrm{O})$ stretching and $\delta_{\text {as }}(\mathrm{O}-\mathrm{Cl}-\mathrm{O})$ bending modes of the perchlorate groups. These bands appear without splitting, as befit uncoordinated anions ${ }^{[39]}$.

The ${ }^{1} \mathrm{H}$ and ${ }^{13} \mathrm{C}$ NMR spectra of all complexes were recorded in $\mathrm{CD}_{3} \mathrm{CN}$ solution, and assigned (see experimental part) with the aid of HSQC and HMBC 2D heteronuclear experiments, as well as standard 2D homonuclear COSY spectra. In some cases, full unequivocal assignment of the signals was not possible. The NMR data show a number of signals and structure very similar to those of the corresponding free ligands, but the broadening of the signals and the changes in their chemical shifts, especially for the aromatic protons, indicate that the systems are in fast exchange within the NMR timescale. Under these conditions the observed chemical shifts are weighted averages of those of the free ligand and complex present in solution.

\subsection{Solid state structures}

Single crystals of compounds $\left[\mathrm{Na}\left(\mathbf{L}^{\mathbf{1}}\right)\right]\left(\mathrm{ClO}_{4}\right),\left[\mathrm{Na}\left(\mathbf{L}^{\mathbf{4}}\right)\right]\left(\mathrm{ClO}_{4}\right),\left[\mathrm{Na}\left(\mathbf{L}^{\mathbf{5}}\right)\right]\left(\mathrm{ClO}_{4}\right)$ and $\left[\mathrm{Na}\left(\mathbf{L}^{\mathbf{6}}\right)\right]\left(\mathrm{ClO}_{4}\right)$ suitable for X-ray diffraction analysis were obtained by the different methods described under the experimental section. All compounds contain the complex cation $\left[\mathrm{Na}\left(\mathbf{L}^{n}\right)\right]^{+}(n=1,4,5$ or 6$)$ and a non-coordinated perchlorate anion involved in hydrogen-bonding interaction with the $\mathrm{NH}$ groups of benzimidazole or aniline units. Views of the structures of the complexes are shown in Fig. 1, Fig. 2, Fig. 3, while bond distances of the metal coordination environments are given in Table 2. In all complexes the metal ion is directly bound to all donor atoms of the ligand, resulting six- $\left(\mathbf{L}^{\mathbf{1}}\right)$, seven- $\left(\mathbf{L}^{\mathbf{4}}\right)$ or eight-coordinate $\left(\mathbf{L}^{\mathbf{5}}\right.$ and $\left.\mathbf{L}^{\mathbf{6}}\right)$ complexes. The distances between the metal ions and the tertiary amine nitrogen atoms are considerably longer than those to the nitrogen atoms of the pendant arms. In fact, the distances between the metal ion and the pivotal nitrogen atoms in $\left[\mathrm{Na}\left(\mathbf{L}^{5}\right)\right]^{+}[2.830(1) \AA]$ and $\left[\mathrm{Na}\left(\mathbf{L}^{6}\right)\right]^{+}[2.905(2) \AA]$ are considerably longer than the sum of the van der Waals radius of $\mathrm{N}(1.55 \AA)^{[40]}$ and the ionic radius of $\mathrm{Na}^{+}(1.18 \AA \text { for } \mathrm{CN} 8)^{[41]}$. Thus, the pivotal nitrogen atoms provide very weak interactions with $\mathrm{Na}^{+}$. In the case of those complexes with ligands containing aniline pendants $\left(\mathbf{L}^{4}\right.$ and $\mathbf{L}^{6}$ ) the oxygen atoms of the crown moiety provide the strongest interaction of the ligand to the metal ion, as expected due to the classification of these metal ions as hard in the Pearson $\mathrm{HSAB}^{[42]}$. The distances between the $\mathrm{Na}^{+}$ion and the nitrogen atoms of benzimidazole groups in $\left[\mathrm{Na}\left(\mathbf{L}^{\mathbf{1}}\right)\right]^{+}$and $\left[\mathrm{Na}\left(\mathbf{L}^{\mathbf{5}}\right)\right]^{+}$are however very similar to the $\mathrm{Na}-\mathrm{O}$ distances, which indicates that the benzimidazole pendant arms provide a stronger binding to $\mathrm{Na}^{+}$than the aniline ones. 


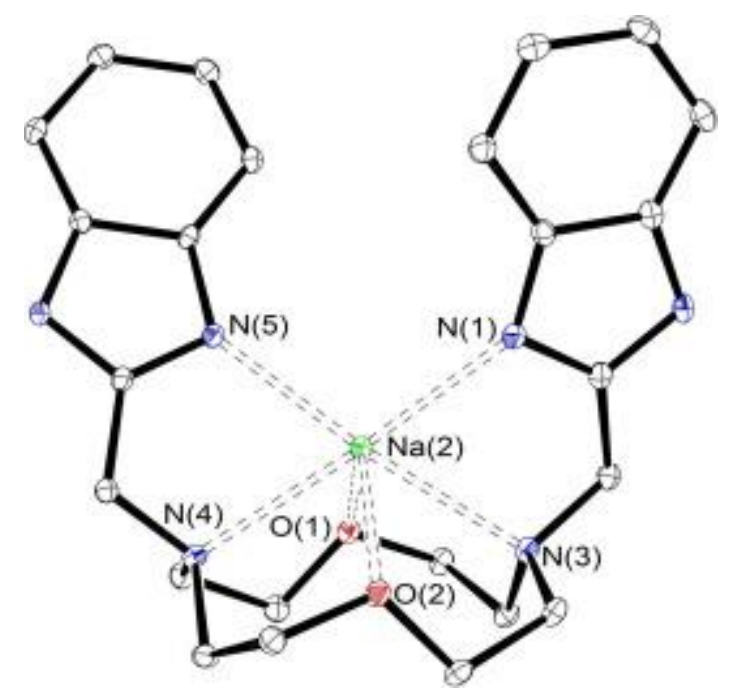

Fig. 1. View of the $\left[\mathrm{Na}\left(\mathrm{L}^{1}\right)\right]^{+}$cation present in crystals of $\left[\mathrm{Na}\left(\mathrm{L}^{1}\right)\right]\left(\mathrm{ClO}_{4}\right)$. The ORTEP plot is drawn at the $30 \%$ probability level. Hydrogen atoms are omitted for the sake of simplicity.

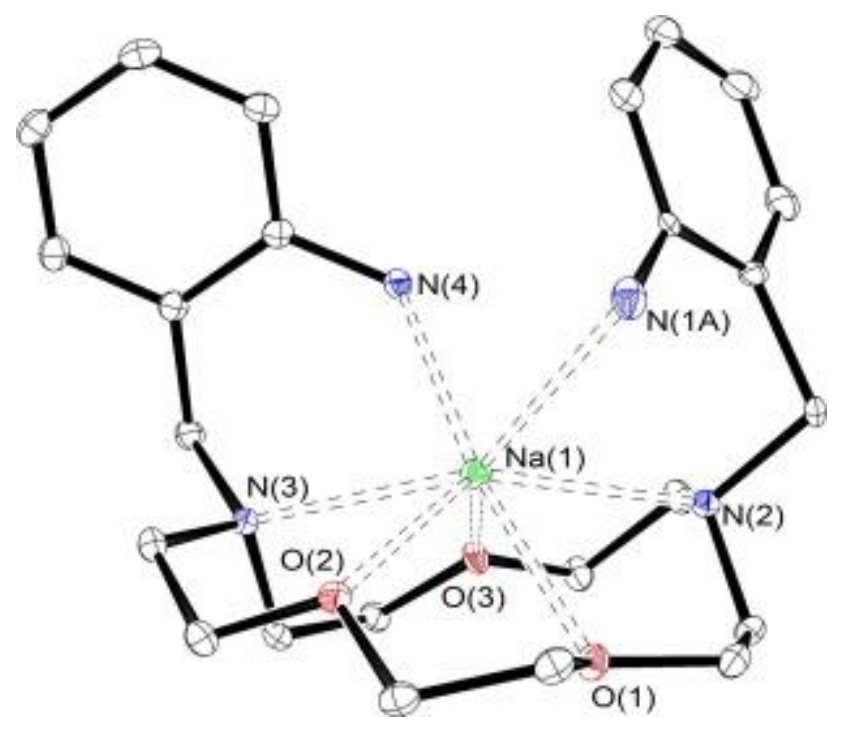

Fig. 2. View of the $\left[\mathrm{Na}\left(\mathbf{L}^{4}\right)\right]^{+}$cation present in crystals of $\left[\mathrm{Na}\left(\mathbf{L}^{4}\right)\right]\left(\mathrm{ClO}_{4}\right)$. The ORTEP plot is drawn at the $30 \%$ probability level. Hydrogen atoms are omitted for the sake of simplicity.

It is worthy to note that the complexes of $\mathrm{Na}^{+}$or $\mathrm{K}^{+}$with ligands derived from aza-crowns are not very common, especially those with ligands derived from 1,7-diaza-12-crown-4. A simple search into the Cambridge Crystallographic Structural Data base (CSD) led to only seven results for compounds derived from 1,7-diaza-12-crown-4 with sodium and although they contain the crown moiety they are actually macrobicycles or cyclophane structures where the $\mathrm{Na}^{+}$ion is placed well above the crown plane. If the search is performed for compounds including the [1,7-diaza-15-crown-5-Na $]^{+}$moiety, only 17 results appear in the hit list but among them 15 are cryptands, one of them is a cyclophane, while only one of the hits includes the crown ether with two o-metoxy-phenyl pendant arms. This compound ${ }^{[43]}$ presents shorter Na-N distances (2.443 and $2.491 \AA$ ) involving the pivotal nitrogen atoms than $\left[\mathrm{Na}\left(\mathbf{L}^{4}\right)\right]^{+}$, while the $\mathrm{Na}-\mathrm{O}_{\text {crown }}$ distances are $2.282,2.360$ and $2.308 \AA$. Finally, if the search is performed for compounds containing the 1,10-diaza-18crown-6 fragment and sodium 114 crystal structures are found: 23 of them contain the crown ether with different pendant arms and the remaining structures contain cyclophanes or cryptands, often the $(2,2,2)$ cryptand sodium complex. The mean Na-O and Na-N distances observed for the 23 lariat ether 
derivatives are 2.45 and $2.64 \AA$, respectively, and therefore the $\mathrm{Na}-\mathrm{O}$ distances for $\left[\mathrm{Na}\left(\mathbf{L}^{6}\right)\right]^{+}$are slightly longer than the average of these structures, while the Na-N distances in $\left[\mathrm{Na}\left(\mathbf{L}^{6}\right)\right]^{+}$are slightly shorter.

For comparison, single crystals of the analogous $\mathrm{K}^{+}$compound $\left[\mathrm{K}\left(\mathbf{L}^{6}\right)\right]\left(\mathrm{ClO}_{4}\right)$ were also prepared. The $\left[\mathrm{Na}\left(\mathbf{L}^{6}\right)\right]^{+}$and $\left[\mathrm{K}\left(\mathbf{L}^{6}\right)\right]^{+}$cation complexes adopt very similar structures (Fig. 3). The metal ion sits on a center of symmetry, with the eight donor atoms of the ligand defining a distorted cubic polyhedron around the metal ions. The same coordination polyhedron is observed for $\left[\mathrm{Na}\left(\mathbf{L}^{5}\right)\right]^{+}$and similar coordination environment was previously observed for the $\left[\mathrm{Pb}\left(\mathbf{L}^{6}\right)\right]^{+}$complex in the solid state ${ }^{[44]}$.
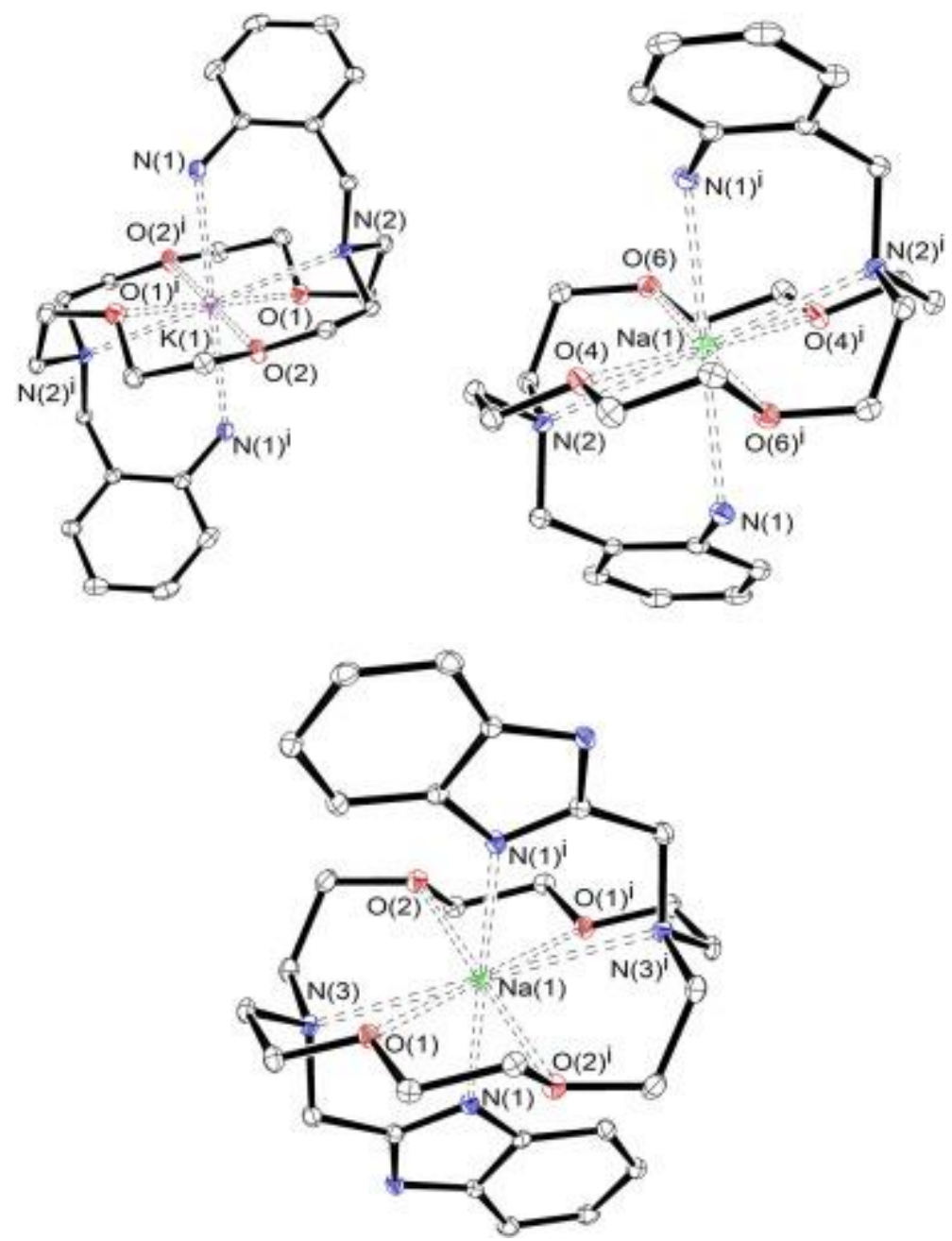

Fig. 3. View of the $\left[\mathrm{Na}\left(\mathbf{L}^{5}\right)\right]^{+},\left[\mathrm{Na}\left(\mathbf{L}^{6}\right)\right]^{+}$and $\left[\mathrm{K}\left(\mathbf{L}^{6}\right)\right]^{+}$cations present in crystals of $\left[\mathrm{Na}\left(\mathbf{L}^{5}\right)\right]\left(\mathrm{ClO}_{4}\right),\left[\mathrm{Na}\left(\mathbf{L}^{6}\right)\right]\left(\mathrm{ClO}_{4}\right)$ and $\left[\mathrm{K}\left(\mathbf{L}^{6}\right)\right]\left(\mathrm{ClO}_{4}\right)$ respectively. The ORTEP plots are drawn at the $30 \%$ probability level. Hydrogen atoms are omitted for the sake of simplicity.

The pendant arms of the ligands in compounds $\left[\mathrm{Na}\left(\mathbf{L}^{\mathbf{1}}\right)\right]^{+}$and $\left[\mathrm{Na}\left(\mathbf{L}^{4}\right)\right]^{+}$are pointing to the same side of the macrocyclic mean plane, resulting in a syn conformation with the metal ion above the plane defined by the donors of the crown moiety. However, the ligands derived from 4,13-diaza-18-crown-6 adopt anti conformations in both the $\mathrm{Na}^{+}$and $\mathrm{K}^{+}$complexes as a result of the relatively large size of the crown fragment compared to the size of the metal ion that now fits inside the hole.

A search in the CSD for compounds containing the 1,10-diaza-18-crown-6 moiety and potassium provides 526 structures, but excluding $(2,2,2)$ and $(2,2,1)$ cryptate derivatives only 75 entries remain. The mean K-O 
and K-N distances observed for these complexes are 2.805 and $2.95 \AA$, respectively. Thus, the corresponding distances observed for $\left[\mathrm{K}\left(\mathbf{L}^{6}\right)\right]^{+}$are slightly shorter than this average.

Crystals of $\left[\mathrm{Na}\left(\mathbf{L}^{7}\right)\right]\left(\mathrm{ClO}_{4}\right)$ contain the cation $\left[\mathrm{Na}\left(\mathbf{L}^{7}\right)\right]^{+}$and a non-coordinated perchlorate anion. Fig. 4 displays a view of the structure of the cation, while selected bond lengths and angles of the metal coordination environment are given in Table 2. The metal ion is asymmetrically placed inside the macrobicyclic cavity. The metal ion is six-coordinated, being bound to the pyridyl nitrogen N(3), one of the secondary amine nitrogen atoms, $\mathrm{N}(4)$, and the oxygen atoms of the crown moiety, $\mathrm{O}(1), \mathrm{O}(2)$ and $\mathrm{O}(3)$. The bond distances are similar to those observed for similar compounds in the CSD. The distances between the $\mathrm{Na}^{+}$ion and $\mathrm{N}(2)$ and $\mathrm{N}(5)$ amount to 3.63 and $3.25 \AA$, respectively, which indicates that these nitrogen atoms do not coordinate to the metal ion. As observed for the complexes of $\mathbf{L}^{4}$ and $\mathbf{L}^{6}$ the oxygen atoms of the crown moiety provide the strongest interaction of the ligand to the metal ion. The secondary amine nitrogen atom $\mathrm{N}(2)$ is involved in an intramolecular hydrogen-bonding interaction with one of the oxygen atoms of the crown moiety and one of the pivotal nitrogen atoms: $[\mathrm{N}(2) \cdots \mathrm{O}(3) 3.401(5) \AA$; $\mathrm{N}(2)-\mathrm{H}(2) \cdots \mathrm{O}(3)$ $\left.2.62 \AA, \mathrm{N}(2)-\mathrm{H}(2)-\mathrm{O}(3) 150.9^{\circ} ; \mathrm{N}(2) \cdots \mathrm{N}(5) 2.964(6) \AA ; \mathrm{N}(2)-\mathrm{H}(2) \cdots \mathrm{N}(5) 2.43 \AA, \mathrm{N}(2)-\mathrm{H}(2)-\mathrm{N}(5) 121.1^{\circ}\right]$. This interaction was also observed in the crystal structure of the free ligand ${ }^{[45]}$.

Table 2. Bond distances $(\AA)$ of the metal coordination environments in $\mathrm{Na}^{+}$and $\mathrm{K}^{+}$complexes.

\begin{tabular}{llllll}
\hline & {$\left[\mathrm{NaL}^{\mathbf{1}}\right]^{+}$} & & {$\left[\mathrm{NaL}^{4}\right]^{+}$} & & {$\left[\mathrm{NaL}^{5}\right]^{+}$} \\
\hline $\mathrm{Na}(2)-\mathrm{O}(1)$ & $2.442(1)$ & $\mathrm{Na}(1)-\mathrm{O}(1)$ & $2.466(1)$ & $\mathrm{Na}(1)-\mathrm{O}(1)$ & $2.595(1)$ \\
$\mathrm{Na}(2)-\mathrm{O}(2)$ & $2.409(1)$ & $\mathrm{Na}(1)-\mathrm{O}(2)$ & $2.436(1)$ & $\mathrm{Na}(1)-\mathrm{O}(2)$ & $2.530(1)$ \\
$\mathrm{Na}(2)-\mathrm{N}(1)$ & $2.434(1)$ & $\mathrm{Na}(1)-\mathrm{O}(3)$ & $2.378(1)$ & $\mathrm{Na}(1)-\mathrm{N}(1)$ & $2.556(1)$ \\
$\mathrm{Na}(2)-\mathrm{N}(3)$ & $2.548(1)$ & $\mathrm{Na}(1)-\mathrm{N}(1 \mathrm{~A})$ & $2.67(2)$ & $\mathrm{Na}(1)-\mathrm{N}(3)$ & $2.830(1)$ \\
$\mathrm{Na}(2)-\mathrm{N}(4)$ & $2.535(1)$ & $\mathrm{Na}(1)-\mathrm{N}(2)$ & $2.663(2)$ & & \\
$\mathrm{Na}(2)-\mathrm{N}(5)$ & $2.412(1)$ & $\mathrm{Na}(1)-\mathrm{N}(3)$ & $2.681(2)$ & & \\
& & $\mathrm{Na}(1)-\mathrm{N}(4)$ & $2.539(2)$ & & \\
& & & {$\left[\mathrm{KL}^{6}\right]^{+}$} & & {$\left[\mathrm{NaL}^{7}\right]^{+}$} \\
\hline $\mathrm{Na}(1)-\mathrm{O}(1)$ & $2.511(2)$ & $\mathrm{K}(1)-\mathrm{O}(1)$ & $2.650(2)$ & $\mathrm{Na}(1)-\mathrm{O}(1)$ & $2.310(4)$ \\
$\mathrm{Na}(1)-\mathrm{O}(2)$ & $2.545(2)$ & $\mathrm{K}(1)-\mathrm{O}(2)$ & $2.649(2)$ & $\mathrm{Na}(1)-\mathrm{O}(2)$ & $2.479(3)$ \\
$\mathrm{Na}(1)-\mathrm{N}(1)$ & $2.557(2)$ & $\mathrm{K}(1)-\mathrm{N}(1)$ & $2.869(2)$ & $\mathrm{Na}(1)-\mathrm{O}(3)$ & $2.299(4)$ \\
$\mathrm{Na}(1)-\mathrm{N}(2)$ & $2.905(2)$ & $\mathrm{K}(1)-\mathrm{N}(2)$ & $2.904(2)$ & $\mathrm{Na}(1)-\mathrm{N}(1)$ & $2.514(4)$ \\
& & & & $\mathrm{Na}(1)-\mathrm{N}(3)$ & $2.668(4)$ \\
& & & & $\mathrm{Na}(1)-\mathrm{N}(4)$ & $2.525(4)$ \\
\hline
\end{tabular}

\subsection{Spectrophotometric titrations}

The coordination of $\mathrm{Na}^{+}$to receptors $\mathbf{L}^{1}-\mathbf{L}^{\mathbf{8}}$ was studied by means of spectrophotometric titrations in acetonitrile solution. The UV-Vis spectra of the receptors containing benzimidazole pendant arms $\left(\mathbf{L}^{1}, \mathbf{L}^{3}\right.$ and $\mathbf{L}^{5}$ ) show two bands at ca. 277 and $284 \mathrm{~nm}$ (Fig. 5 and Supplementary material), which have been assigned as $\pi^{*} \leftarrow \pi$ singlet-singlet transitions $\left({ }^{1} L_{a} \leftarrow \mathrm{S}_{0}\right.$ and ${ }^{1} L_{b} \leftarrow \mathrm{S}_{0}$, where the two excited states are labeled by ${ }^{1} L_{a}$ and ${ }^{1} L_{b}$ following the suggestion of Platt $)^{[46,47]}$. The spectra also show a third maximum at $c a$. $245 \mathrm{~nm}$. Addition of the metal ion salt causes appreciable modification of the spectral patterns. In particular, metal ion addition induces blue shifts of the bands centered at 277 and $284 \mathrm{~nm}$ as their intensity slightly increases. Metal ion addition also provokes a blue shift of the band at $c a .245 \mathrm{~nm}$ as its intensity decreases. These results indicate the coordination of the benzimidazole groups to the metal ion in this solvent. 
The UV-Vis spectra of free receptors $\mathbf{L}^{2}, \mathbf{L}^{4}$ and $\mathbf{L}^{6}-\mathbf{L}^{8}$ recorded in acetonitrile solution (Fig. 6 and Supplementary material) are dominated by two absorption bands with maxima at $c a .250$ and $290 \mathrm{~nm}$ corresponding to $\mathrm{E}_{2}$ and $\mathrm{B} \pi \rightarrow \pi^{*}$ bands of the aromatic rings, respectively ${ }^{[48]}$. Metal ion addition again results in the shift of these absorption bands to shorter wavelengths as their intensity decreases. However, the spectral changes observed for the macrobicyclic receptors $\mathbf{L}^{7}$ and $\mathbf{L}^{8}$ are less pronounced than those of the lariat ether analogs; the complex of $\mathbf{L}^{\mathbf{8}}$ was not isolated, but spectrophotometric titrations were performed for comparative purposes.

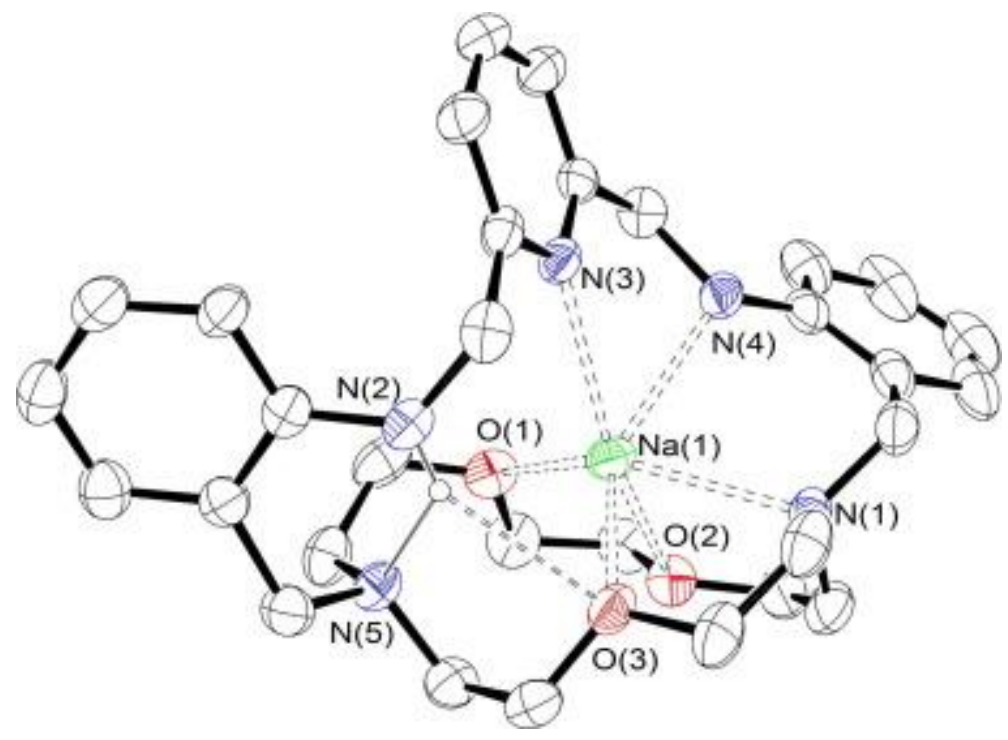

Fig. 4. View of the $\left[\mathrm{Na}\left(\mathbf{L}^{7}\right)\right]^{+}$cation present in crystals of $\left[\mathrm{Na}\left(\mathbf{L}^{7}\right)\right]\left(\mathrm{ClO}_{4}\right)$. The ORTEP plot is drawn at the $30 \%$ probability level. Hydrogen atoms, except those involved in intramolecular hydrogen-bonding interaction, are omitted for the sake of simplicity.

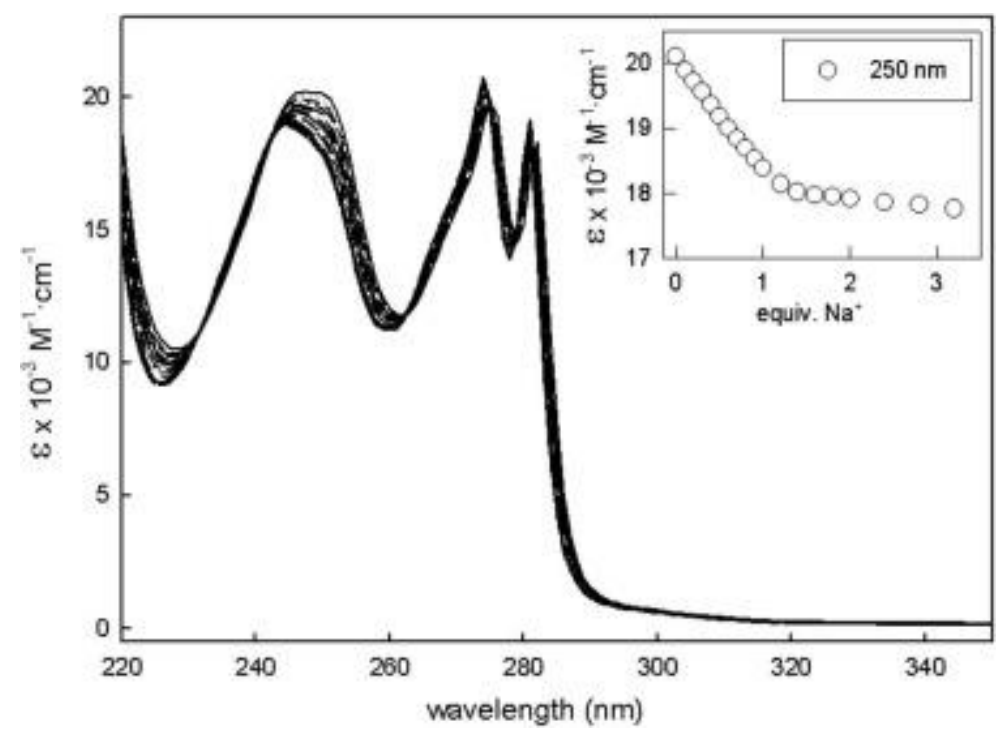

Fig. 5. Spectra recorded over the course of the titration of a $10^{-4} \mathbf{M}$ solution of $\mathbf{L}^{3}$ with a standard solution of $\left.\mathrm{Na}_{(\mathrm{ClO}}\right)$. Inset: titration profile at $250 \mathrm{~nm}$. 


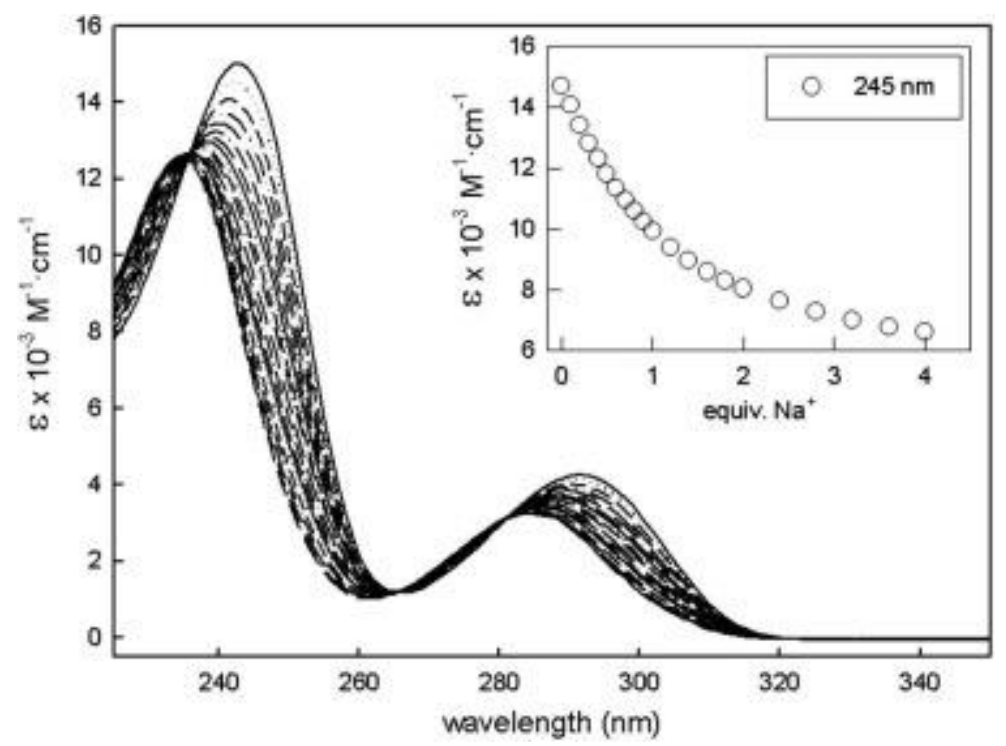

Fig. 6. Spectra recorded over the course of the titration of a $10^{-4} \mathrm{M}$ solution of $\mathbf{L}^{4}$ with a standard solution of $\mathrm{Na}\left(\mathrm{ClO}_{4}\right)$. Inset: titration profile at $245 \mathrm{~nm}$.

Nonlinear least-squares analysis of the titration profiles (absorbance against the number of equivalents of $\mathrm{Na}^{+}$, see insets of Fig. 5, Fig. 6 and Supplementary material) clearly indicates the formation of 1:1 complexes in every case; the corresponding association constants are summarized in Table 3. The results show that those ligands containing benzimidazole pendant arms form more stable complexes than those containing aniline pendants. This might be attributed to two reasons: (i) the formation of more stable 5-membered chelates in the former case, instead of the 6-membered chelates formed upon coordination of aniline pendants; (ii) the higher basicity of the benzimidazole pendants ( $\mathrm{p} K_{\mathrm{a}}$ of 2-methylbenzimidazole 6.2) compared with that of aniline groups $\left(\mathrm{p} K_{\mathrm{a}} \text { of 2-methylaniline } 4.4\right)^{[49]}$. This is in line with the sharper inflection points observed for the titration profiles of $\mathbf{L}^{\mathbf{1}}, \mathbf{L}^{3}$ and $\mathbf{L}^{\mathbf{5}}$ close to the 1:1 stoichiometry in comparison to $\mathbf{L}^{2}, \mathbf{L}^{4}$ and $\mathbf{L}^{6}$. For a given series of ligands containing the same pendant arms, those deriving from diaza-12-crown-4 provide the complexes with the lowest stability, while the receptors derived from 15crown-5 and 18-crown-6 form complexes with comparable stabilities. This can be attributed to the better fit of the crown moiety size and the metal ion for the latter group of ligands. If we compare the stability of these complexes (Table 3) with those of the parent crown ethers ${ }^{[50]}$ in acetonitrile $\left(\log K\left[\mathrm{Na}(12 \text {-crown-4) }]^{+}=3.31\right.\right.$; $\log K\left[\mathrm{Na}(15 \text {-crown-5) }]^{+}=5.1 ; \log K\left[\mathrm{Na}(18 \text {-crown-6) }]^{+}=4.6\right)\right.$ we find very similar values for the complexes including aniline moieties but clearly more stable complexes when including benzimidazole pendants due to the factors commented before. Moreover, the stability constants determined for the complexes of $\mathbf{L}^{5}\left(\log K_{\mathrm{Na}}=6.19\right)$ and $\mathbf{L}^{6}\left(\log K_{\mathrm{Na}}=4.49\right)$ are higher than that reported for 4,13-diaza-18crown-6 $\left(\log K_{\mathrm{Na}}=3.92\right)^{[51]}$ in the same solvent, which indicates that the coordination of the pendant arms present in $\mathbf{L}^{\mathbf{5}}$ and $\mathbf{L}^{\mathbf{6}}$ provides an important contribution to the overall stability of the complexes, particularly when benzimidazole pendants are present.

On the other hand, the complexes formed with the macrobicyclic receptors $\mathbf{L}^{7}$ and $\mathbf{L}^{8}$ present low stabilities $\left(\log K_{\mathrm{Na}}<4\right)$. This is probably a consequence of the poor fit between the macrocyclic cavity and the size of $\mathrm{Na}^{+}$, and the rigidity introduced by the macrobicyclic structure that render more difficult the approximation of both secondary amine donor atoms simultaneously to the metal ion. This is in line with the asymmetric coordination of $\mathrm{Na}^{+}$into the cavity of $\mathbf{L}^{7}$ evidenced by the solid state structure. 
Table 3. Binding constants of $\mathrm{Na}^{+}$complexes obtained from spectrophotometric titrations in $\mathrm{CH}_{3} \mathrm{CN}$ solution at $25^{\circ} \mathrm{C}$. $\mathrm{Log} K_{\mathrm{Na}}$ refers to $\mathrm{L}^{n}+\mathrm{Na}^{+} \leftrightarrows\left[\mathrm{NaL}^{\mathrm{n}}\right]^{+}$.

\begin{tabular}{llll}
\hline Ligand & Ring size & $\log \boldsymbol{K}_{\mathbf{N a}}$ & $\lambda_{\max } \mathbf{n m}(\boldsymbol{\varepsilon})$ \\
\hline $\mathrm{L}^{1}$ & 12 & $5.89(3)$ & $247(13446)$ \\
& & & $275(13323)$ \\
& & & $282(12511)$ \\
$\mathrm{L}^{2}$ & 12 & $3.37(1)$ & $243(18365)$ \\
& & & $291(5116)$ \\
$\mathrm{L}^{3}$ & 15 & $6.10(5)$ & $247(20176)$ \\
& & & $275(19783)$ \\
& & & $282(18308)$ \\
$\mathrm{L}^{4}$ & 15 & $4.26(5)$ & $243(15026)$ \\
& & & $291(4242)$ \\
$\mathrm{L}^{5}$ & 18 & $6.19(5)$ & $247(13582)$ \\
& & & $275(13149)$ \\
$\mathrm{L}^{6}$ & 18 & $4.49(5)$ & $282(12346)$ \\
& & & $291(22482)$ \\
$\mathrm{L}^{7}$ & 15 & $3.34(1)$ & $252(32216)$ \\
& & & $290(11133)$ \\
$\mathrm{L}^{8}$ & 18 & $3.41(1)$ & $253(35226)$ \\
& & & $290(11349)$ \\
\hline
\end{tabular}

\section{Conclusions}

Receptors $\mathbf{L}^{1}-\mathbf{L}^{7}$ form stable complexes with $\mathrm{Na}^{+}$. The crystal structures of $\left[\mathrm{Na}\left(\mathbf{L}^{\mathbf{1}}\right)\right]\left(\mathrm{ClO}_{4}\right),\left[\mathrm{Na}\left(\mathbf{L}^{4}\right)\right]\left(\mathrm{ClO}_{4}\right)$, $\left[\mathrm{Na}\left(\mathbf{L}^{5}\right)\right]\left(\mathrm{ClO}_{4}\right)$ and $\left[\mathrm{Na}\left(\mathbf{L}^{6}\right)\right]\left(\mathrm{ClO}_{4}\right)$ show that the bibracchial lariat ethers use all the donor atoms of the crown moiety and one of each pendant arm, but the cryptanddisplays an asymmetric coordination where one tertiary amine and one secondary aminedonor atoms remain uncoordinated. Bonding distances as well as the stability constants in acetonitrile solution confirm that the coordination of the pendant arms provides an important contribution to the overall stability of the complexes, particularly when benzimidazolependants are present rending more stable complexes, even more than cryptand complexes of the same size. Compared with the parent crown ethers the stability increases when the side arms contain benzimidazole moieties but remains about the same order when anilineside arms are present.

\section{Acknowledgements}

The authors thank Xunta de Galicia (CN2012/011) for generous financial support. I. C.-B and A. R.-R. thank the Spanish Ministerio de Educación y Ciencia (FPU program) for predoctoral fellowships.

\section{Supplementary material}

CCDC 959336, 959333, 959337, 959334, 959332 and 959335 contains the supplementary crystallographic data for $\left[\mathrm{NaL}^{1}\right]\left(\mathrm{ClO}_{4}\right),\left[\mathrm{NaL}^{4}\right]\left(\mathrm{ClO}_{4}\right),\left[\mathrm{NaL}^{5}\right]\left(\mathrm{ClO}_{4}\right),\left[\mathrm{NaL}^{6}\right]\left(\mathrm{ClO}_{4}\right),\left[\mathrm{KL}^{6}\right]\left(\mathrm{ClO}_{4}\right)$ and $\left[\mathrm{NaL}^{7}\right]\left(-\mathrm{ClO}_{4}\right)$. These data can be obtained free of charge from The Cambridge Crystallographic Data Centre via 
www.ccdc.cam.ac.uk/ data request/cif. Supplementary data associated with this article can be found, in the online version, at https://doi.org/10.1016/j.ica.2013.11.022.

\section{References}

[1] C.J. Pedersen, J. Am. Chem. Soc. 89 (1967) 2495.

[2] C.J. Pedersen, J. Am. Chem. Soc. 89 (1967) 7017.

[3] C.J. Pedersen, J.-M. Lehn, D.J. Cram, Resonance 6 (2001) 71.

[4] G.W. Gokel, S.H. Korzeniowski, Macrocyclic Polyether Synthesis, Springer, Berlin, 1982.

[5] J.W. Steed, Coord. Chem. Rev. 215 (2001) 171.

[6] G.W. Gokel, in: G.W. Gokel (ed.), Comprehensive Supramolecular Chemistry, vol. 1, Lariat Ethers; Pergammon, New York, 1996, p. 97.

[7] G.W. Gokel, W.M. Leevy, M.E. Weber, Chem. Rev. 248 (2004) 2723.

[8] H.-J. Schneider, A.K. Yatsimirsky, Chem. Soc. Rev. 37 (2008) 263.

[9] V.K. Gupta, M.K. Pal, A.K. Singh, Anal. Chim. Acta 631 (2009) 161.

[10] P. Buhlmann, E. Pretsch, E. Bakker, Chem. Rev. 98 (1998) 1593.

[11] M.H. Hyun, J. Sep. Sci. 26 (2003) 242.

[12] X.-J. Ju, S.-B. Zhang, M.-Y. Zhou, R. Xie, L. Yang, L.-Y. Chu, J. Hazard. Mater. 167 (2009) 114.

[13] N. Basilio, L. Garcia-Rio, J.C. Mejuto, M. Perez-Lorenzo, J. Org. Chem. 71 (2006) 4280.

[14] S. Shirakawa, K. Yamamoto, M. Kitamura, T. Ooi, K. Maruoka, Angew. Chem., Int. Ed. 44 (2005) 625.

[15] A.V. Tsukanov, A.D. Dubonosov, V.A. Bren, V.I. Minkin, Chem. Heterocycl. Compd. 44 (2008) 899.

[16] I. Moczar, P. Huszthy, A. Mezei, M. Kadar, J. Nyitrai, K. Toth, Tetrahedron 66 (2010) 350.

[17] V.I. Minkin, A.D. Dubonosov, V.A. Bren, A.V. Tsukanov, ARKIVOK (2008) 90.

[18] A. Casnati, A. Pochini, R. Húngaro, C. Bocchi, F. Ugozzoli, R.J.M. Egberink, H. Struijk, R. Lugtenberg, F. de Jong, D.N. Reinhoudt, Chem. Eur. J. 2 (1996) 436.

[19] K. Marijeta, L. Tusek-Bozic, L. Frkanec, Chem. Med. Chem. 3 (2008) 1478.

[20] C. Platas-Iglesias, D. Esteban, V. Ojea, F. Avecilla, A. de Blas, T. Rodríguez-Blas, Inorg. Chem. 42 (2003) 4299.

[21] L. Vaiana, M. Regueiro-Figueroa, C. Platas-Iglesias, D. Esteban-Gómez, A. de Blas, T. Rodríguez-Blas, Inorg. Chem. 46 (2007) 8217.

[22] L. Vaiana, D. Esteban-Gómez, M. Mato-Iglesias, C. Platas-Iglesias, A. de Blas, T. Rodríguez-Blas, Eur. J. Inorg. Chem. 3 (2009) 400. 
[23] I. Carreira-Barral, A. Rodríguez-Rodríguez, M. Regueiro-Figueroa, D. EstebanGómez, C. PlatasIglesias, A. de Blas, T. Rodríguez-Blas, Inorg. Chim. Acta 370 (2011) 270.

[24] A. Rodríguez-Rodríguez, I. Carreira-Barral, M. Regueiro-Figueroa, D. EstebanGómez, C. PlatasIglesias, A. de Blas, T. Rodríguez-Blas, Polyhedron 31 (1) (2012) 402.

[25] M. Regueiro-Figueroa, D. Esteban-Gómez, C. Platas-Iglesias, A. de Blas, T. Rodríguez-Blas, Eur. J. Inorg. Chem. (2007) 2198.

[26] D. Esteban, D. Bañobre, A. de Blas, T. Rodríguez-Blas, R. Bastida, A. Macías, A. Rodríguez, D.E. Fenton, H. Adams, J. Mahía, Eur. J. Inorg. Chem. (2000) 1445.

[27] C. Rodríguez-Infante, D. Esteban, F. Avecilla, A. de Blas, T. Rodríguez-Blas, J. Mahía, A.L. Macedo, C.F.G.C. Geraldes, Inorg. Chim. Acta 317 (2001) 190.

[28] N. Su, J.S. Bradshaw, X.X. Zhang, P.B. Savage, K.E. Krakowiak, R.M. Izatt, J. Heterocycl. Chem. 36 (1999) 771.

[29] D. Esteban-Gómez, C. Platas-Iglesias, A. de Blas, L. Fabbrizzi, T. Rodríguez-Blas, Chem. Eur. J. 14 (2008) 5829.

[30] W.C. Wolsey, J. Chem. Educ. 50 (1973) A335.

[31] W.J. Geary, Coord. Chem. Rev. 7 (1971) 81.

[32] P. Gans, A. Sabatini, A. Vacca, Talanta 43 (1996) 1739.

[33] G.M. Sheldrick, SADABS Version 2.10, University of Göttingen, Germany, 2004.

[34] SHELX. G.M. Sheldrick, Acta Crystallogr., Sect. A 64 (2008) 112.

[35] L.J. Farrugia, J. Appl. Crystallogr. 32 (1999) 837.

[36] SUPERFLIP. L. Palatinus, G. Chapuis, J. Appl. Crystallogr. 40 (2007) 786.

[37] DIRDIF99. P.T. Beurskens, G. Beurskens, R. de Gelder, R.O. García-Granda, S. Gould, R. Israel, J.M.M. Smits, The DIRDIF-99 Program System, Technical Report of the Crystallography Laboratory, University of Nijmegen, The Netherlands, 1999.

[38] DIRDIF-2008 - A Computer Program for Crystal Structure Determination by Patterson Methods and Direct Methods applied to Difference Structure Factors. P.T. Beurskens, G. Beurskens, R. Gelder, J.M.M. Smits, S. Garcia-Granda, R.O. Gould, Crystallography Laboratory, Radbound University Nijmegen, Toernooiveld 1, 6526 ED Nijmegen, The Netherlands, 2008.

[39] K. Nakamoto, in: Infrared and Raman Spectra of Inorganic and Coordination Compounds, third, J. Wiley, New York, Chichester, Brisbane and Toronto, 1972, p. 142.

[40] A. Bondi, J. Phys. Chem. 68 (1964) 441.

[41] R.D. Shannon, Acta Crystallogr., Sect. A 32 (1976) 751.

[42] R.G. Pearson, R.J. Mawby, Halogen Chem. 3 (1967) 55.

[43] A.P. de Silva, H.Q.N. Gunaratne, T. Gunnlaugsson, M. Nieuwenhuizen, Chem. Commun. (1996) 1967. 
[44] D. Esteban, F. Avecilla, C. Platas-Iglesias, J. Mahía, A. de Blas, T. Rodríguez-Blas, Inorg. Chem. 41 (2002) 4337.

[45] D. Esteban-Gómez, T. Enríquez-Pérez, R. Ferreirós-Martínez, M. Mato-Iglesias, C. Platas-Iglesias, A. de Blas, T. Rodríguez-Blas, Eur. J. Inorg. Chem. (2010) 5027.

[46] G. Berden, W.L. Meerts, E. Jalviste, J. Chem. Phys. 103 (1995) 9596.

[47] J.R. Platt, J. Chem. Phys. 19 (1951) 101.

[48] R.M. Silverstein, C. Bassler, Spectrometric Identification of Organic Compounds, Wiley Int., 1967.

[49] D.D. Perrin, B. Dempsey, E.P. Serjeant, PKa Prediction for Organic Acids and Bases, Chapman \& Hall, London, 1981.

[50] F. Arnaud-Neu, R. Delgado, S. Chaves, Pure Appl. Chem. 75 (1) (2003) 71 (IUPAC Technical Report).

[51] H.-J. Buschmann, Inorg. Chim. Acta 120 (1986) 125. 